\title{
Efficacy of Growth Regulators on Flowering of Gerbera (Gerbera jamesonii B.) cv. Goliath in Open Field Condition
}

Bishnupada Giri, Sashikala Beura

10.18805/ag.D-5380

\begin{abstract}
Background: Application of plant bioregulators at specific concentration modify growth, flowering, flower yield and post harvest quality of flowers. Growth promoters like auxin, gibberellins and cytokinin modify physiological process by accelerating plant growth while growth retardant like cycocel and abscisic acid inhibit plant growth. But in open field cultivation of gerbera, little is known about use of growth regulators on flowering regulation. A good knowledge on use of growth regulators in gerbera is required before going to any recommendations. The current study aimed to standardize suitable bioregulators on flower production in gerbera in open field condition.

Methods: The study was carried out in premises of Biotechnology cum Tissue Culture Centre, Odisha University of Agriculture and Technology, Bhubaneswar during 2015-16 and 2016-17. Apart from control eight treatments of growth regulators were used like $\mathrm{GA}_{3}$ @ 100 ppm and 150 ppm, cycocel @ 700 ppm and 800 ppm with or without amino acids as foliar spray. The observation were recorded from 5 randomly selected plant within each replication of treatment for different floral parameters.

Result: The result revealed that days taken to flower bud initiation and days taken to flowering was minimum in $\mathrm{GA}_{3} @ 100$ ppm + amino acid. The stalk length of flower was maximum in treatment $\mathrm{GA}_{3} @ 150$ ppm + amino acid while largest flower diameter, maximum number of flowers and longest bloom life was observed in treatment with cycocel @ 700 ppm + amino acid. Maximum stalk thickness was found in treatment with cycocel @ 800 ppm + amino acid. The present work will be a complementary contribution to the researchers and gerbera growers in increasing productivity of this flower crops.
\end{abstract}

Key words: Amino acid, Cycocel, Gibberellins.

\section{INTRODUCTION}

Gerbera (Gerbera jamesonii, B.) also known as 'Transvaal Daisy', 'Barbeton Daisy' or 'African Daisy' belonging to family Asteraceae occupies $5^{\text {th }}$ place as cut flower in international flower trade (Sujatha et al., 2002). It is popular because of its attractive colour, long vase life and suitability for long distant transport (Bose et al. 2003). It is used for fresh and dry flower arrangement, exhibition, decoration, bouquet preparation (Patra et al., 2015). Local and improved cultivar are grown in garden, flower bed, pots, borders, dish garden and rock garden. Flowers are of different colour like white cream, yellow, pink, orange, brick red, scarlet, salmon, maroon and bicolor and are available in single, semi-double or double form.

Application of plant bio regulators at specific concentration modify growth, flowering, flower yield and post harvest quality of flowers. Growth promoters like auxin, gibberellin and cytokinin modify physiological process by accelerating plant growth while growth retardant like cycocel and abscisic acid inhibit plant growth. Maximum vegetative growth, flower yield and quality was observed in gerbera by application of $\mathrm{GA}_{3} @ 150$ ppm. (Dalal et al., 2009).

Similarly, application of growth retardant like paclobutrazole @ 25 to 100 ppm in gerbera reduce plant spread, increase leaf number/plant, increase chlorophyll content, decrease in stalk length, increase in stalk thickness, number of flowers and flower quality parameters (Bekheta et al., 2008).
Department of Floriculture and Landscaping, College of Agriculture, Odisha University of Agriculture and Technology, Bhubaneswar751 012, Odisha, India.

Corresponding Author: Bishnupada Giri, Department of Floriculture and Landscaping, College of Agriculture, Odisha University of Agriculture and Technology, Bhubaneswar-751 012, Odisha, India. Email: bapugiri8@gmail.com

How to cite this article: Giri, B. and Beura, S. (2021). Efficacy of Growth Regulators on Flowering of Gerbera (Gerbera jamesonii B.) cv. Goliath in Open Field Condition. Agricultural Science Digest. DOI: $10.18805 /$ ag.D-5380.

Submitted: 17-05-2021 Accepted: 09-10-2021 Online: 18-11-2021

\section{MATERIALS AND METHOD}

The present study was conducted in premises of Biotechnology cum Tissue Culture Centre, Odisha University of Agriculture Technology, Bhubaneswar from Nov. to Oct. 2015-16 and 2016-17 in open condition.

The experimental site is situated $63 \mathrm{~km}$ away from Bay of Bengal at an altitude of $25 \mathrm{~m}$ above MSL and extended between $20^{\circ} 15^{\prime}$ North latitude and $85^{\circ} 50^{\prime}$ East longitude. The average rainfall of the site is $1646 \mathrm{~mm}$. The maximum temperature during the experimental period was $38.8^{\circ} \mathrm{C}$ to $40.8^{\circ} \mathrm{C}$ and minimum temperature was $14.1^{\circ} \mathrm{C}$ to $15.2^{\circ} \mathrm{C}$. The relative humidity during the experimental period was $37 \%$ to $94 \%$. The experimental soil was sandy loam with $\mathrm{pH}$ 5.83, EC $0.64 \mathrm{ds} / \mathrm{m}$, OC $0.475 \%$, N $125 \mathrm{~kg} / \mathrm{ha}, \mathrm{P}_{2} \mathrm{O}_{5} 67.1$ 
$\mathrm{kg} / \mathrm{ha}, \mathrm{K}_{2} \mathrm{O} 166.6 \mathrm{~kg} / \mathrm{ha}$. The growing media was composed of soil, FYM and coco peat in 1: 1: 1 proportion.

Earthen pots with a hole at the bottom were used for planting. The pots were filled with soil mixture. Four leaved tissue culture plantlet of gerbera cv. Goliath a variety suitable for protected cultivation was used for planting. A basal dose of NPK @ 10:15:20 g per $\mathrm{m}^{2}$ was applied. The experiment was laid down in completely randomized design (CRD) with nine treatments and three replication per treatments. There were 10 plants per replication and 30 plants per treatment making a total population of 270 plants.

The present experiment comprised with 9 treatments i.e. $\mathrm{T}_{1}$ (Control), $\mathrm{T}_{2}\left(\mathrm{GA}_{3} @ 100 \mathrm{ppm}\right), \mathrm{T}_{3}\left(\mathrm{GA}_{3} @ 150 \mathrm{ppm}\right)$,

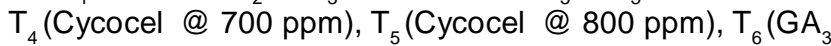
@100 ppm + amino acid @ 2 ml/l), T $\left(G A_{3} @ 150\right.$ ppm + amino acid @ 2 ml/l), T (Cycocel @ 700 ppm + amino acid @ $2 \mathrm{ml} / \mathrm{l}), \mathrm{T}_{9}$ (Cycocel @ 800 ppm + amino acid @ 2 ml/l). For application of treatments to the plants following concentrations of plant bio regulators solution were prepared. With help of a precision balance $100 \mathrm{mg}$ and 150 $\mathrm{mg}$ of $\mathrm{GA}_{3}$ were measured and taken in two beakers separately. Little quantity of sodium hydroxide was added to the beaker for easy solubility. Then the volume was made to 1 litre by adding water in to the beakers thus preparing $100 \mathrm{ppm}$ and $150 \mathrm{ppm}$ of $\mathrm{GA}_{3}$ solution. Similarly, $700 \mathrm{mg}$ and $800 \mathrm{mg}$ of cycocel were measured and taken in two beakers separately. Little quantity of alcohol was added to the beaker for easy solubility and then the volume was made to 1 litre by adding water into the beaker. Thus, 700 ppm and 800 ppm cycocel solution were prepared.

The observation were recorded from 5 randomly selected plant within each replication of treatment for different floral parameters like days taken to flower bud initiation after disbudding, days taken to flowering, stalk length, stalk thickness, number of flower/plant, flower diameter and bloom life. The data collected were analysed statistically following the method of Gomez and Gomez (1984) using one way ANOVA in CRD. A comparison of treatment means were done at $5 \%$ level of significance $(P=0.05)$.

\section{RESULTS AND DISCUSSION}

The result of the experiment obtained in the year 2015-16 and 2016-17 were pooled and presented under following headings.

\section{Days to flower bud initiation after disbudding}

After disbudding of all plants, the days taken to flower bud initiation was counted. The pooled data from both the years showed that the days taken to flower bud initiation (8.83 days) was minimum in $\mathrm{T}_{6}$ (GA @ 100 ppm+ amino acid) which was at par with $\mathrm{T}_{2}$ (GA@ $@ 100$ ppm), T (GA @ 150 ppm+ amino acid) and $T_{3}$ (GA @ 150 ppm) (Table 1). The earliness in flower bud initiation might be attributed to the fact that $G A$ helps in auxin synthesis and enhance metabolism. Phengphachanh (2012) reported that GA application reduce $A B A$ level in plant resulting early bud emergence. The maximum delay in flower bud initiation (22.08 days) was observed in treatment $T_{1}$ (control) where no growth regulator was applied. Similar finding was also observed by Dalal et al. (2009), Emongor et al. (2004) who reported early flower bud emergence by GA application.

\section{Days to flowering}

The days taken to flowering from flower bud emergence was counted. The earliest flowering (15.83 days) was recorded in $T_{6}$ (GA @ 100 ppm+ amino acid) which was at par with $T_{7}$ (GA@150 ppm + amino acid), T2 (GA@ 100ppm) (Table 1). The earliness in flowering might be due to $G A$ application at optimum concentration (100 ppm). Phengphachanh (2012) reported that application of $G A$ reduce level of growth retardant $(A B A)$ in gerbera resulting early flowering. Similar findings have been obtained by Awan et al. (1999), Nair et al. (2002), Rana et al. (2005), Matsumoto et al. (2006), Dalal et al. (2009) with respect to early flowering in gerbera. The maximum delay in flowering (23.50 days) was observed in

Table 1: Impact of plant bio regulators on flowering characters i.e. days taken to flower bud initiation after disbudding, days taken to flowering, lengthof flower stalk and thickness of flower stalk in gerbera cv. Goliath.

\begin{tabular}{|c|c|c|c|c|c|c|c|c|c|}
\hline \multirow[t]{2}{*}{$\begin{array}{l}\text { Treatments } \\
\text { number }\end{array}$} & \multirow{2}{*}{ Treatments } & \multirow{2}{*}{$\begin{array}{l}\text { Days to flower } \\
\text { bud initiation } \\
\text { after disbudding }\end{array}$} & \multirow{2}{*}{$\begin{array}{c}\text { Days } \\
\text { taken to } \\
\text { flowering }\end{array}$} & \multicolumn{3}{|c|}{$\begin{array}{l}\text { Length of flower stalk } \\
\qquad(\mathrm{cm})\end{array}$} & \multicolumn{3}{|c|}{$\begin{array}{l}\text { Thickness of flower stalk } \\
(\mathrm{mm})\end{array}$} \\
\hline & & & & Winter & Summer & Rainy & Winter & Summer & Rainy \\
\hline $\mathrm{T}_{1}$ & Control & 22.08 & 23.50 & 49.25 & 46.94 & 49.17 & 5.69 & 5.17 & 5.58 \\
\hline $\mathrm{T}_{2}$ & GA @ 100 ppm & 9.58 & 16.33 & 52.77 & 48.81 & 52.00 & 6.45 & 6.01 & 6.20 \\
\hline $\mathrm{T}_{3}$ & GA @ 150 ppm & 10.58 & 17.42 & 59.28 & 51.97 & 53.99 & 6.28 & 5.86 & 6.02 \\
\hline $\mathrm{T}_{4}$ & Cycocel @700 ppm & 17.08 & 19.83 & 47.42 & 45.55 & 47.29 & 6.61 & 6.22 & 6.45 \\
\hline $\mathrm{T}_{5}$ & Cycocel @800 ppm & 19.83 & 20.83 & 45.68 & 43.96 & 45.52 & 6.74 & 6.42 & 6.65 \\
\hline $\mathrm{T}_{6}$ & GA @ 100 ppm + AA & 8.83 & 15.83 & 54.68 & 51.33 & 53.92 & 6.62 & 6.24 & 6.43 \\
\hline $\mathrm{T}_{7}$ & GA @ 150 ppm + AA & 9.83 & 16.67 & 61.84 & 54.23 & 55.98 & 6.58 & 6.08 & 6.19 \\
\hline $\mathrm{T}_{8}$ & Cycocel @ 700 ppm + AA & 16.00 & 18.67 & 50.14 & 47.71 & 49.71 & 6.80 & 6.44 & 6.67 \\
\hline \multirow[t]{3}{*}{$\mathrm{T}_{9}$} & Cycocel @ 800 ppm + AA & 18.67 & 19.75 & 47.85 & 46.08 & 47.76 & 6.99 & 6.64 & 6.94 \\
\hline & $\mathrm{SE}(\mathrm{m}) \pm$ & 0.941 & 0.491 & 1.819 & 0.653 & 0.512 & 0.067 & 0.189 & 0.150 \\
\hline & CD (0.05) & 3.07 & 1.4 & 5.93 & 1.86 & 1.46 & 0.19 & 0.62 & 0.49 \\
\hline
\end{tabular}


treatment $T_{1}$ (control) due to no application of growth regulators.

\section{Length of flower stalk}

The pooled data from both the year revealed that in winter season longest stalk length $(61.84 \mathrm{~cm})$ was observed in $T_{7}$ (GA@ 150 ppm+ amino acid) which was at par with $T_{3}$ (GA @ 150 ppm) while minimum stalk length $(45.68 \mathrm{~cm})$ was observed in $\mathrm{T}_{5}$ (Cycocel @ 800 ppm) (Table 1). Increase in stalk length in $T_{7}$ and $T_{3}$ might be due to application of $G A$ @ 150 ppm with or without amino acid. Being a growth promoter Gibberellin induce cell elongation and cell enlargement increasing stalk length. Similar finding was obtained by Pobudkiewicz and Nowak (1992), Sujatha et al. (2009), Dalal et al. (2009), Dogra et al. (2012), Mehraj et al. (2013) and Jamaluddin et al. (2014) by application GA in gerbera. Decrease in flower stalk length in $T_{5}$ (Cycocel @ $800 \mathrm{ppm}$ ) may be due to inhibitory effect of cycocel on cell elongation and cell enlargement which corroborates with the findings of Mohamed (1992) who reported that growth retardant like ethrel decreased stalk length. Similar trend in increase in length of flower stalk was also observed in summer and rainy season.

\section{Thickness of flower stalk}

The pooled data from both the year revealed that in winter season maximum stalk thickness $(6.99 \mathrm{~mm})$ was observed in $T_{9}$ (Cycocel @ 800 ppm + amino acid) which was at par with $\mathrm{T}_{8}$ (Cycocel @ 700 ppm+ amino acid). Increase in stalk thickness in $\mathrm{T}_{9}$ and $\mathrm{T}_{8}$ might be due to application of cycocel and as a growth retardant it checks apical dominance and stem elongation but increases stem thickness.

Similar findings were also obtained by Lin (1961) and Muthumanickam et al. (1999) who stated that application of growth retardant like ethrel increased stalk thickness in gerbera. Thinnest flower stalk $(5.17 \mathrm{~mm})$ was observed in $\mathrm{T}_{1}$ (control) during summer where no growth regulators was applied. Similar trend in increase in stalk thickness was also observed in winter and rainy season.

\section{Number of flowers/plant}

Pooled data from both the year revealed that in winter season maximum number of flowers (15.77/plant) was found in $\mathrm{T}_{8}$ (Cycocel @ 700 ppm+ amino acid) which was at par withT $_{4}$ (Cycocel @700 ppm), T6 (GA @ 100 ppm+ amino acid) and closely followed by $T_{9}$ (Cycocel @ 800 ppm+ amino acid while lowest number of flower (8.43/plant) was recorded in $T_{1}$ (Control).

Increase in flower number in $T_{8}$ and $T_{4}$ may be due to application optimum concentration of Cycocel @ 700 ppm with or without amino acid. Being a growth retardant cycocel inhibits apical dominance and induce bushiness/ dwarfness which resulted in emergence of more number of suckers. When number of suckers increased, the number of flower/ plant increased. Similar finding have been obtained by Mohamed (1992), Muthumanikam et al. (1999) and Kumar et al. (2008) who reported increase in flower number by application of growth retardant like ethrel in gerbera. Besides, Cycocel application another treatment $\mathrm{T}_{6}$ (GA @ 100 ppm+ amino acid) produced more number of flowers/ plant which was very close to best treatment. Similar finding have been obtained by Nair et al. (2002), Sujatha et al. (2002), Dalal et al. (2009), Jamaluddin et al. (2013) in increasing number of flowers/plant in gerbera. The minimum number of flower/plant obtained in $T_{1}$ (Control) may be due to no application of growth regulator. Similar trend in increase in number of flowers/plant was also observed in summer and rainy season.

\section{Flower diameter}

The pooled data from both of the years revealed that in winter season largest flower diameter $(11.53 \mathrm{~cm})$ was observed in $\mathrm{T}_{8}$ (Cycocel @ 700 ppm + amino acid) which was at par with $\mathrm{T}_{6}\left(\mathrm{GA}_{3} @ 100\right.$ ppm + AA), $\mathrm{T}_{9}($ Cycocel @ 800 ppm + AA) and $\mathrm{T}_{4}$ (Cycocel @ 700 ppm) while minimum flower diameter $\left(9.49 \mathrm{~cm}\right.$ ) was observed in $T_{1}$ (control) (Table 2). Increase in flower diameter in $\mathrm{T}_{8}$ and $\mathrm{T}_{4}$ might be due to application of optimum concentration of cycocel@ 900 ppm with or without

Table 2: Impact of plant bio regulators on flowering characters i.e. total number of flowers/plant, flower diameter and bloom life of hybrid gerbera cv. Goliath.

\begin{tabular}{|c|c|c|c|c|c|c|c|c|c|c|}
\hline \multirow{2}{*}{$\begin{array}{l}\text { Treatments } \\
\text { number }\end{array}$} & \multirow{2}{*}{ Treatments } & \multicolumn{3}{|c|}{$\begin{array}{c}\text { Total number of flowers } \\
\text { /plant }\end{array}$} & \multicolumn{3}{|c|}{$\begin{array}{l}\text { Flower diameter } \\
\qquad(\mathrm{cm})\end{array}$} & \multicolumn{3}{|c|}{$\begin{array}{l}\text { Bloom life } \\
\text { (days) }\end{array}$} \\
\hline & & Winter & Summer & Rainy & Winter & Summer & Rainy & Winter & Summer & Rainy \\
\hline $\mathrm{T}_{1}$ & Control & 8.43 & 5.59 & 6.93 & 9.49 & 8.40 & 8.76 & 11.65 & 7.52 & 8.54 \\
\hline $\mathrm{T}_{2}$ & GA @ 100 ppm & 13.17 & 8.75 & 10.25 & 10.95 & 9.57 & 9.84 & 16.82 & 10.57 & 11.40 \\
\hline $\mathrm{T}_{3}$ & GA @ 150 ppm & 11.68 & 7.59 & 8.85 & 10.57 & 9.07 & 9.64 & 15.73 & 9.90 & 10.82 \\
\hline $\mathrm{T}_{4}$ & Cycocel @ 700 ppm & 14.84 & 10.59 & 12.17 & 11.21 & 9.91 & 10.25 & 19.00 & 12.02 & 12.96 \\
\hline $\mathrm{T}_{5}$ & Cycocel@ @ 800 ppm & 12.69 & 9.51 & 10.76 & 10.86 & 9.53 & 9.95 & 17.86 & 11.27 & 12.27 \\
\hline $\mathrm{T}_{6}$ & GA @ 100 ppm + AA & 14.51 & 10.01 & 11.18 & 11.29 & 9.90 & 10.11 & 18.75 & 11.40 & 12.21 \\
\hline $\mathrm{T}_{7}$ & GA @ 150 ppm + AA & 13.26 & 9.09 & 9.92 & 10.82 & 9.40 & 9.90 & 17.65 & 10.75 & 11.57 \\
\hline $\mathrm{T}_{8}$ & Cycocel @700 ppm + AA & 15.77 & 12.09 & 13.17 & 11.53 & 10.19 & 10.57 & 21.34 & 13.11 & 13.98 \\
\hline \multirow[t]{3}{*}{$\mathrm{T}_{9}$} & Cycocel @ 800 ppm + AA & 14.25 & 10.43 & 12.18 & 11.25 & 9.80 & 10.18 & 19.84 & 12.19 & 13.29 \\
\hline & SE $(m) \pm$ & 0.409 & 0.279 & 0.239 & 0.112 & 0.197 & 0.161 & 0.371 & 0.573 & 0.772 \\
\hline & $\mathrm{CD}(0.05)$ & 1.33 & 0.79 & 0.68 & 0.32 & 0.64 & 0.53 & 1.21 & 1.87 & 2.52 \\
\hline
\end{tabular}


amino acid. Being a growth retardant cycocel result delay flowering which help in accumulation of photosynthates in plant resulting larger flower. Highest chlorophyll content in treatment with cycocel is also an evidence of maximum dry matter production resulting large flower. Similar findings have been obtained by Nair et al. (2002) by application of cycocel in gerbera. The role of growth retardant in increasing flower diameter was also proved by Mohamed (1992) with application of ethrel in gerbera. The smallest flower diameter was recorded in $\mathrm{T}_{1}$ (control) which was due to no application of growth regulator in gerbera. Similar trend in increase in flower diameter was also observed in summer and rainy season.

\section{Bloom life}

The pooled data from both the years revealed that in winter season maximum bloom life (21.34 days) was observed in $\mathrm{T}_{8}$ (Cycocel $700 \mathrm{ppm}+$ amino acid) which was closely followed by $T_{9}$ (Cycocel @ 800 ppm+ amino acid) while minimum bloom life (11.65 days) was observed in $\mathrm{T}_{1}$ (control) (Table 2). Increase in bloom life might be due to application of cycocel. As discussed earlier, due to delay in flowering and more chlorophyll content in treatment with cycocel, there was more reserve of photosynthates in flower which prolong bloom life. Similar finding have been reported by Jamaluddin et al. (2014) by application of growth retardant like ethrel in gerbera. The shortest bloom life was observed in $\mathrm{T}_{1}$ (control) due to no application of growth regulators. Similar trend in increase in bloom life was also observed in summer and rainy season.

\section{CONCLUSION}

From the above findings it can be concluded that combination of $\mathrm{GA}_{3} @ 100$ ppm and amino acid performed best with respect to days to flower bud initiation and flowering. Maximum stalk length was achieved by application of $\mathrm{GA}_{3} @ 150$ ppm+ amino acid while maximum number of flowers/plant, diameters of flower and bloom life were observed by application of CCC @ 700 ppm + amino acid. Maximum stalk thickness was found in treatment with cycocel @ 800 ppm+ amino acid. The result of this study will be torch bearer for the researcher as well as gerbera grower for enhancing flower production under open field condition.

\section{REFERENCES}

Awan, I.U., Baloch, M.S., Sadozai, N.S., Sulemani, M.Z. (1999). Stimulatory effect of $\mathrm{GA}_{3}$ and IAA on ripening process, kernel development and quality of gerbera. Pakistan Journal of Biological Sciences. 2: 410-412.

Bekheta, M.A., Abbas, S.E.L., Kobisy, O.S., Mahgoub, M.H. (2008). Influence of selenium and paclobutrazole on growth, metabolic activities and anatomical characters of Gerbera. Australian Journal of Basic and applied Science. 2(4): $1284-1297$.

Bose, T.K., Yadav, L.P., Pal, P, Parthasarathy, V.P. and Das, P. (2003). Commercial flowers (2 $2^{\text {nd }}$ Edn.). Naya Udyog, Calcutta. pp. 4.
Dalal, S.R., Somavanshi, A.V., Karale, G.D. (2009). Effect of gibberellic acid on growth, flowering, yield and quality of gerbera under polyhouse conditions. International Journal of Agricultural Sciences. 5(2): 355-356.

Dogra, S., Pandey, R.K., Bhat, D.J. (2012). Influence of gibberellic acid and plant geometry ongrowth, flowering and production in gerbera under Jammu agro climate. International Journal of Pharma and Bio Sciences. 3(4): 1083-1090.

Emongor, V.E. (2004). Effect of gibberellic acid on post harvest quality and vase life of gerbera cut flowers. Journal of Agronomy. 3(3): 191-195.

Gomez, K.A. and Gomez, A.A. (1984). Statistical Procedures for Agricultural Research. JohnWiley Sons, New York. pp. 680.

Jamaluddin, A.F.M., Mehraj, H., Taufique, T., Ona, A.F., Parvin, S. (2014). Foliar application of gibberellic acid on growth and flowering of gerbera cultivars. Journal of Bioscienceand Agriculture Research. 02(1): 52 -58.

Kumar, V., Singh, A. R., Singh, R.P., Katyar, P.N. (2008). Effect of $\mathrm{GA}_{3}$ and Ethrel on growth, flowering and yield attributes of gerbera. Annals of Horticulture. 1(1): 54-57.

Lin, R.S. (1961). Effect of 1-aminocyclopropane-1 carboxylic acid and Ethrel on Phalenopsis plantlets in vitro. Journal Agricultural Research China. 41(2): 178-186.

Matsumoto, T.K. (2006). Gibberellic acid and Benzyl adenine promote early flowering and vegetative growth of gerbera hybrids. Horticultural Science Journal. 41: 131-135.

Mehraj, H., Taufique, T., Ona, A.F., Roni, M.Z.K., Jamal Uddin, A.F.M. (2013). Effect of spraying frequency of gibberllic acid on growth and flowering in gerbera. Journal of Experimental Biosciences. 4(2): 7-10.

Mohamed, S.M. (1992). Influence of some growth regulators on growth and flowering of gerbera. Journal of Applied Science. 7: 653-667.

Muthumanickam, D., Rajamani, K., Jawaharal, M. (1999). Effect of micro nutrient on flower production in gerbera. Journal of Ornamental Horticulture. 2(2): 131-132.

Nair, S.A., Sujatha, K., Medhi, R.P. (2002). Performance of gerbera cultivars in Bay Island. Indian Journal of Horticulture. 59(8): 322-325.

Patra, S.K., Beura, S., Sashani, T. (2015). Efficacy of $\mathrm{GA}_{3}$ on growth and flowering regulation of in vitro raised hybrid gerbera under shade net. Agri. Sci. Digest. 35(3): 173-177.

Phengphachanh, B., Naphrom, D., Bundhitty. W., Potapohn, N. (2012). Effect of day length and $\mathrm{GA}_{3}$ on flowering and endogenous hormone level in Rhynchostylisgigantia. Journal of Agricultural Science. 4(4): 217-222.

Pobudkiewicz, A. and Nowak. J. (1992). The effect of gibberellic acid on growth and flowering of gerbera. Folia Horticulture. 4(2): $35-42$.

Rana, P., Kumar, J., Kumar M. (2005). Response of $\mathrm{GA}_{3}$, plant spacing and planting depthon growth, flowering and corm production in gladiolus. Journal of Ornamental Horticulture. 8(1): 41-44.

Sujatha, K., Gowda, J.V.N., Khan, M.M. (2002). Effect of different fertigation level on gerbera under low cost greenhouse. Journal of Ornamental Horticulture. 5(1): 54-59. 